\title{
活性炭吸着アクラルビシンの基礎的検討
}

\author{
小林 理・高谷育男・牧野達郎・西連寺意勲 - 本橋久彦 1 ・ 杉政征夫・武宮省治 \\ 岡本 堯 $^{21}$, 麻賀太郎・增沢千尋 ${ }^{3)} \cdot$ 玉井拙夫 ・飯森和人 ${ }^{4)}$, 村上賢二 ${ }^{5)}$
}

\section{Experimental study of activated carbon adsorbed aclarubicin}

For anticancer effects on metastatic lymph node, activated carbon adsorbed anticancer drugs were injected preoperatively into the present study, the adsorption isotherm of activated carbon adsorbed aclarubicin (ACR) was measured and its stability in solution was investigated. The adsorption isotherms of $5-\mathrm{FU}$ and $\mathrm{MMC}$ were prepared and compared with that of aclarubicin. In the adsorption isotherm of $\mathrm{CH}-40$ activated carbon, the amount of ACR adsorbed was better than that of 5 -FU and MMC. The amount of ACR adsorbed for $\mathrm{CH}-1500$ activated carbon was also better than that for $\mathrm{CH}-40$ activated carbon. The stability of ACR adsorbed on activated carbon solution decreased as the concentration of the activated carbon increased. The stability when the activated carbon and ACR concentration ratio was constant in saline solution was $100 \%$ after 2 hours and $40 \%$ after 7 days.

Osamu Kobayashi . Ikuo Takatani . Tatsuro Makino $\cdot$ Taro Asaga Motonori Sairenji $\cdot$ Yukio Sugimasa $\cdot$ Shoii Takemiya . Chihiro Masuzawa $\cdot$ Hisahiko Motohashi $\cdot$ Takashi Okamoto*1), Setsuo Tamai . Kazuto Iimori*2), Kenji Murakami*31 key words : gastric cancer, activated carbon, $A C R$

炭素微粒子活性炭の持っている吸着活性を利用 して, 種々の制癌剤を吸着させた新しい剂型が開 発研究されている。制癌剂吸着活性炭は，投与方 法を工夫することにより，目的部位に高濃度の制 癌用を到達させることが可能である。この性質を

*1) Department of Surgery, "25 Department of Gastroenterology, ${ }^{\text {*3) }}$ Department of Clinical Laboratory, Kanagawa Cancer Center Hospital 神奈川県立がんセ ンター, 1) 外科第三科， 2) 第四科， ${ }^{3}$ 第二科

4) 内科第二科, 5) 検直
利用して 5-フルオロウラシル吸着炭素微粒子奬 濁液を胃壁内注入し, 胃癌の薬物的リンパ節郭清 の可能性を報告してきた ${ }^{1 \sim 3}$. 今回は, 活性炭吸着 アクラルビシンの吸着等温線の測定と水溶液中で の安定性を検討した.

さらに，5-フルオロウラシル(5-FU) とマイト マイシンC $(\mathrm{MMC})$ の吸着等温線を作製し, アク ラルビシン $(\mathrm{ACR})$ の吸着等温線と比較検討した ので報告する.

\section{方 法}

実験使用薬剂は ACR (ACR・HCL 原末, 三楽), $5-\mathrm{FU}(250 \mathrm{mg} / 5 \mathrm{ml}$, アンプル : $5-\mathrm{FU}$, 協和), MMC(原木：マイトマイシン, 協和)を用いた。 活 性炭はミツピシ\# 40(三菱化成)，ミツピシ\# 1500 $\mathrm{A}$ (三菱化成)を使用した。分散補助剤としてポリ ビニルピロリドンを使用した。制癌剤濃度は HPLC 法で測定した.

\section{（1）吸着等温線の作製}

(1) ミッビシ\# 40 (以後\# 40 と略す)の吸着等温 線: \# 40 活性炭の制癌剤吸着能を ACR, 5-FU, MMC で比較検討した，吸着等温線の作製は，活 性炭と薬剤の吸着能を $37^{\circ} \mathrm{C}$ 生食中で測定した. 薬剂と活性炭の濃度比をさまざまにかえて $37^{\circ} \mathrm{C}$ の生食中に 1 時間振逷し, 水相中の遊離薬剤濃度 を測定した。

(2) ミッピシ\#1500 A (以後\# 1500)の吸着等温 線：\#1500 活性炭の ACR 吸着能を測定した. ま た, 吸着時の [活性炭/薬剤] 濃度比に対する [吸 着量/活性炭] の関係を検討した。

（2）活性炭吸着アクラルピシンの水溶液中で の安定性

\# 40 活性炭吸着アクラルビシンの水溶液中濃度 


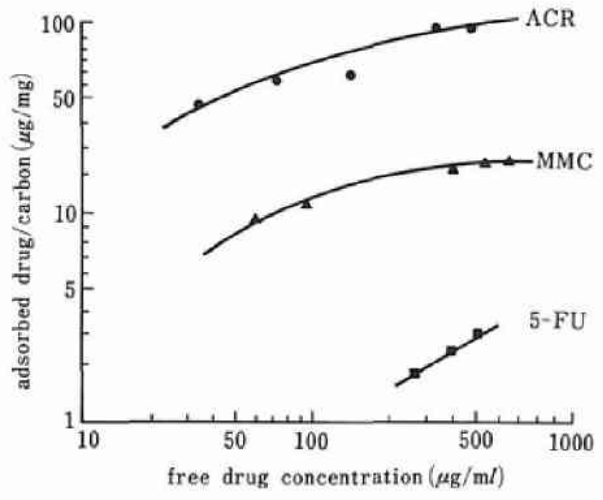

园 1 adsorption isotherm of ACR, $\mathrm{MMC}$ and 5-FU to $\# 40$ carbon

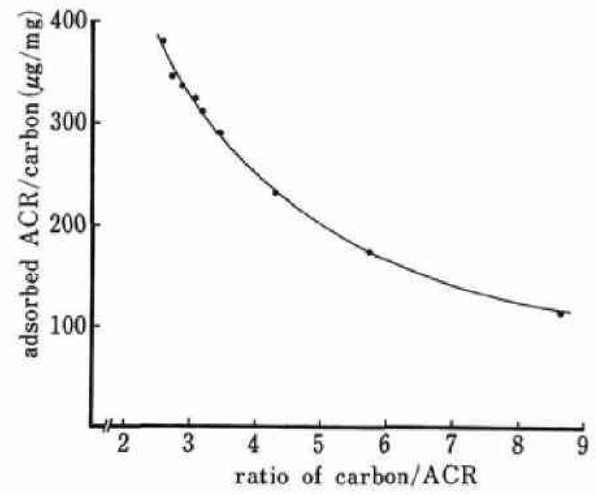

図 3 the influence of carbon/ACR ratio on adsorption of ACR to activated carbon $(\# 1,500)$

を経時的に測定し, ACR 濃度から各種溶液での 安定性を検討した。

使用した溶液は, 生食, PBS, Tris buffer, dog serum である.

\section{結 果}

\section{（1）吸着等温線}

(1) \#40の吸着等温線：測定した吸着等温線を 図 1 に示す。この結果, ACR の被吸着量が 5-FU や MMCにくらへてもっともよく, また遊離濃度 も十分であった。

(2) \# 1500 の吸着等温線：測定した吸着等温線 を図 2 に示す.この結果, \# 1500 活性炭の ACR 被 吸着量は\# 40 よりも良好であった。また, ACR 遊 離濃度は有効濃度内で幅広く遊離していた，吸着 時の [\# 1500/ACR］濃度比に対する [吸着 ACR

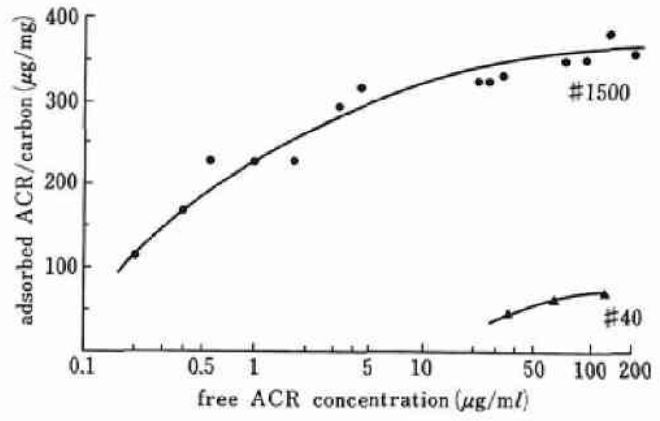

图 2 adsorption isotherm of ACR to activated carbon

表 1 stability of ACR-CH after 2 hours

\begin{tabular}{ccccc}
\hline $\begin{array}{c}\mathrm{ACR} \\
(\mathrm{mg} / \mathrm{m} l)\end{array}$ & $\begin{array}{c}\text { carbon } \\
(\mathrm{mg} / \mathrm{m} l)\end{array}$ & $\mathrm{pH}$ & kind & $\begin{array}{c}\text { remaining(\%) } \\
\text { after } 2 \text { hrs }\end{array}$ \\
\hline 5.0 & 0 & 7.4 & PBS & 100.6 \\
5.0 & 5.0 & 7.4 & PBS & 95.2 \\
5.0 & 10.0 & 7.4 & PBS & 71.7 \\
5.0 & 15.0 & 7.4 & PBS & 57.8 \\
5.0 & 20.0 & 7.4 & PBS & 54.4 \\
5.0 & 25.0 & 7.4 & PBS & 55.3 \\
\hline
\end{tabular}

PBS : phosphate buffer saline

表 2 stability of ACR-CH after several time

\begin{tabular}{|c|c|c|c|c|c|c|c|}
\hline \multirow{2}{*}{$\begin{array}{l}\mathrm{ACR} \\
(\mathrm{mg} \\
/ \mathrm{m} l)\end{array}$} & \multirow{2}{*}{$\begin{array}{c}\text { carbon } \\
(\mathrm{mg} \\
/ \mathrm{m} l)\end{array}$} & \multirow{2}{*}{ kind } & \multirow{2}{*}{ Initial } & \multicolumn{4}{|c|}{ remaining $(\%)$ after } \\
\hline & & & & $2 \mathrm{hrs}$ & & 3 days & \\
\hline & & & & & & & \\
\hline & & & & & & 16.7 & \\
\hline 5.0 & 15.0 & Tris & $(100)$ & 93.3 & 63.4 & 32.9 & 27. \\
\hline 5.0 & 15.0 & $\begin{array}{l}\text { dog } \\
\text { serum }\end{array}$ & (100) & 93.8 & 49.3 & 33.1 & 32.9 \\
\hline
\end{tabular}

PBS : phosphfte buffer saline

Tris : tris buffer

量/\#1500] の関係を図 3 に示す。この結果，たと えば ACR の遊離濃度が $10 \mu \mathrm{g} / \mathrm{m} l$ となる活性炭 吸着アクラルビシン愻濁液を調製するには, 図 2 より\# 1500 活性炭 $1 \mathrm{mg}$ 当り $310 \mu \mathrm{g}$ の ACR を吸 着させる必要があり, 図 3 から [\# 1500/ACR] 濃 度比が 3.2 となるような組成比で活性炭吸着アク ラルビシン憅濁液を調製すればよいことがわかっ た.

（2）活性炭吸着アクラルビシンの水溶液中で の安定性

PBS を溶液としたときの活性炭濃度差による 
2 時間後の安定性を表 1 に示す。この結果, 活性 炭の濃度が高いほど安定性がわるくなった，活性 炭と ACR の濃度比を一定にしたときの溶液別の 安定性を表 2 に示す。この結果，生食では 2 時間 後 100\%，7 日後 40\%であった。 pH 7.4 の dog serum では, 2 時間後 $93.8 \%, 7$ 日後は $32.9 \%$ で あった。

\section{考 察}

リンパ節転移のある胃癌の手術成績は，転移の ない症例にくらべて満足できるものではない、リ ンパ節転移があると思われる進行胃癌の切除成績 を向上させるために，腹膜の切除範囲やリンパ節 郭清の拡大が試みられているが，自ずと限界があ る.そこで，筆者らは，手術で完全に郭清するこ とが困難なリンパ節に対する制癌効果を目的とし て萩原ら ${ }^{4}$ の開発した活性炭吸着制癌剂による胃 癌のリンパ節転移の治療を開始した。

最近では，薬剤に種々の改良を加えて目的部位 にもっとも効果的に到達し，高濃度，長期間の制 癌効果をめざし，なおかつ副作用の軽減を目的と した drug delivery system(DDS) の概念が研究開 発されてきた，炭素微粒子活性炭の薬剂吸着性お よU゙リンパ指行性は DDS の一種であり，特にリ ンパ節に対する targeting chemotherapy に有力 な治療法と思われる。そこで, 胃癌のリンパ節転 移に対する制癌効果(薬物的郭清)を目的とした 5FU 吸着炭素微粒子活性炭 (\#40) 㿟濁液を作製

し, 胃壁内注入した。

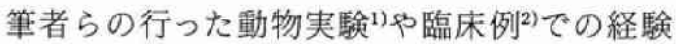
では，胃壁内注入した活性炭奬濁液は速やかに所 属リンパ節に到達しており，転移リンパ節の $25 \%$ に稔濁液が移行していた。また，摘出リンパ節の 制癌剤濃度は, 注入後 10 日でも高い濃度を保って いた，特に，薬物的郭清の標的となる第 3 群や大 動脈周囲リンパ節に有効濃度以上の制癌剂が到達 していだ゙.これらのことから, 制癌荗吸着活性炭 はリンパ節転移に対する targeting chemotherapy として有望であることが判明した. そこで， より有効な活性炭吸着製郕を開発する目的で今回
の検討を行った.

制癌剂吸着活性炭による実験腫瘍に対する効 果 ${ }^{5,65}$ が報告されている。臨床では，胃癌に対する 術前内視鏡下注入療法 ${ }^{7)}$ や癌性胸腹膜炎に有効で あるとされている8 . 今回, 筆者らが検討したとこ ろによると,アクラルビシンの活性炭への吸着性 は，5-FUや MMCよりも高く，また\# 1500 活性 炭は\# 40 活性炭よりも吸着性が大きいことが判明 した。ささらに，今回得られた吸着等温線を用いる ことにより，種々の遊離濃度を有する活性炭吸着 製剤を調製することが可能である。

\section{結 語}

アクラルビシンの活性炭への吸着性は高く, ま た種々の遊離濃度の活性炭吸着製剂の調製が可能 である、

\section{文 献}

1）小林 理, 本橋久彦, 岡本 堯・他: 5-FU 吸着炭素 微粒子の臨床応用. 癌と化学療法 $13: 2230-2232$, 1986.

2) 小林 理, 本橋久彦, 岡本 勢・他：抗癌剤吸着活性 岸の術前内視鏡下注入による胃癌リンパ節転移の治 療。癌の臨床 $34: 299-304,1988$.

3) 小林 理, 本橋久彦, 岡本 圭・他：5-FU 吸着炭䒺 微柆子萢濁液胃壁内注入による骨癌の薬物的リンパ節 郭清一-5-FU 摆度からみた可能性一。癌と化学療法 $15: 619-624,1988$.

4) 萩原明於：活性炭吸着マイトマイシン製鼡の開発とそ の臨床応用のための基礎的研究. 秋田医学 10 ： 187-229, 1983.

5）今田敏夫, 天野富悠, 松本昭彦・他：活性炭抢よび工 ロジール吸着制癌剂の基䃈実験的研究. Drug Delivery System 3:255-261, 1988.

6) 萩原明於, 高橋俊雄, 上田 忠・他：活性炭吸着ペフ ロマイシンの癌リンバ節転移に対する抗腫瘍性、癌の 臨床 $34: 447-450,1988$

7）萩原明於，高橋俊雄，上田 忠・他：胃癌に対する吸 着剂吸着マイトマイシンC 製剂(MMC- $\mathrm{CH} 44$ ) の術前 内視鏡下注入療法。癌と化学療法 10:2588-2564, 1983.

8) Hagiwara, A., Takahashi, T., Lee, R. et al. : Chemotherapy for carcinomatous peritonitis and pleuritis with MMC-CH, mitomycin C adsorbed on activated carbon particles. Cancer 59:245-251, 1987. 